\title{
Tobin's q, RoA, Diversification and Risk
}

\author{
Reza Tehrani ${ }^{1}$, Banafsheh Farhangzadeh ${ }^{2}$ \\ ${ }^{1}$ Associate professor of Tehran University, Tehran, Iran \\ ${ }^{2}$ Master of Financial Management in Tehran University, Tehran, Iran \\ E-mail address: a_b_farhangzadeh@yahoo.com
}

Keywords: "tobin's q"; "firm performance"; "risk"; "return on asset"; "diversification"

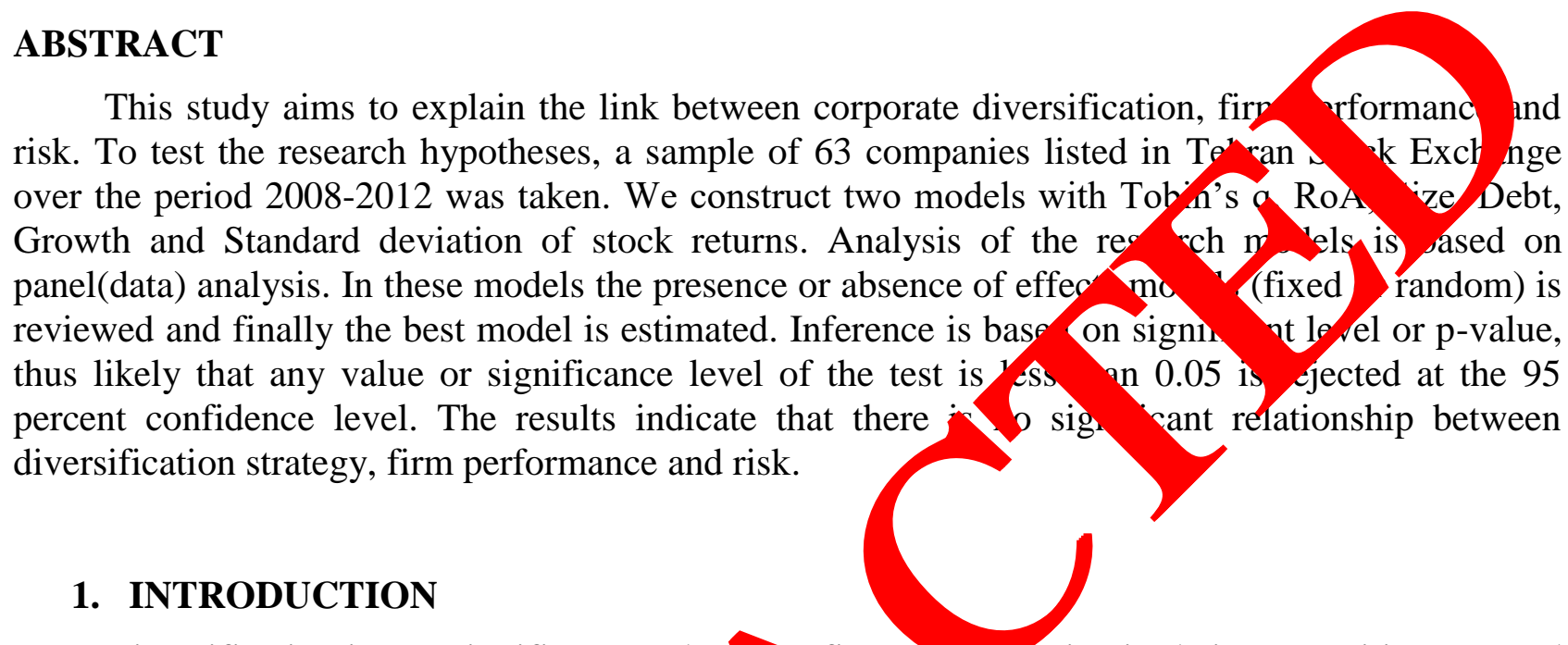

Diversification is one significant methoo firms uso wo maintain their competitiveness and enhance their profitability. Firms seek diversil atry otegy in order to achieve value creation through economic of scope, financial economies, $r$ marke power(Chen and $\mathrm{Yu}, 2012)$.

Since the 70th the academic researc to $\mathrm{ch} k$ the relation between diversification and firm performance(Kahloul,2010). Pre uus s dies sh wed different foundings about the relation between diversification and fi $\mathrm{m}$ some studies found a negative relation between diversification strategy and serforma (e.g.,Berger and Ofek,1995; Wernerfelt and Montgomery, 1988; Martin and Sayrak w while ot found a positive relation(e.g; Maksimovic and Phillips, The diversificatio strategy fortutes a field of investigation for management risk researches(Kahlo 1,201\} It's ofte) perceived by both practical and academicians that corporate diversification a vs educe firm risk. However, the literature contains little empirical evidence on the important on porate diversification on firm risk(Anderson et al.,2011).

2 THEC RETICAL BACKGROUND

The me of the diversification-performance relation, probably one of the most studied in the literature, is far from being exhausted (Palich and al, 2000). Since the 70th the academic research tried to check the relation between diversification strategy and firm performance. Nowadays, the problematic of the firm activity perimeter evolution is an interesting subject so much in industrial economy, in strategy or in finance.

Researches show that some factors have been caused the trend toward diversification during 1960 and 1970. Studies indicate that diversity in companies cause to reduce internal management costs. Rapid growth of management science led to this idea that extract of management is not employing experimental knowledge of one specific industry, but to apply the tools and principles of management. Overall at the global level management principles suggest that professional management can control different companies in financial terms. Subsequent research indicates companies during 1980 and 1990 have again have turned into centralization. Studies show that 
factors such as increased volatility and turmoil in the industry, managers' centralization to increase share value, to accommodate growth and the emergence of new ideas about the management of the company, has been caused refocusing the company.

The present paper is interested to the double impact of the performance and risk. In Lang and Stulz (1994) and Kahloul and Hallara (2010) an objective continuous measure of the strategic diversity of the firm based on the Herfindahl index has been used. In the present work, we also use the Herfindahl index. Our work is concentrated on panel modeling analyses.

\section{LITERATURE REVIEW}

The literature of corporate diversification and the puzzle surrounding whether diversification gives rise to discount or premium, was previously surveyed by three prominent article in and Sayrak (2003), Stein (2003) and Maksimovic and Phillips (2007). Martin and Sayr k (2003) vey the literature on corporate diversification through two separate channels: cross so nal studi, of the link between corporate diversification and firm value on one hand and gituc stud; is in patterns of corporate diversification through time on the other. The sur ey su. diversification discount may not be the result of corporate diversifjea af en all In contrast, diversification discount may result from measurement issues or sy use of ample bias. Stein (2003) studies the strand of literature which questions the ciency of no ate investment in the presence of asymmetric information and agency prob ms. is focus s as mainly on the literature, which addresses the issue of efficient capital al action a sjoms through external capital markets and within firm allocation of capital thro gh its internal cà cal market.

Diversification discount or premium is explaine by various costs and benefits arising from corporate diversification. The costs arising from corpo diversific ation are theoretically justified by agency arguments (Amihud and Lev, 1981; Jensen, Q6; Sh1 Ifer \& Vishny, 1989; Jensen \& Murphy, 1990), inefficient investment due to i ceeking auntles (Scharfstein, 1998; Scharfstein \& Stein, 2000; Rajan et al., 2000; Choe \& Yin, 200s d by more recent theories that suggest the existence of a discount is consistent with the lo ma lmizing behavior of the firm (Fluck \& Lynch,1999; Zuckerman,1999;Mats 2001;C mes \& Livdan,2004). Similarly the benefits of corporate diversification, which gi rise diversi ation premium, can originate from the theories of an efficient internal capito nson,1975; Williamson,1970; Stein,1997), debt coinsurance (Shleifer \& Vir any,1992 conomles of scope (Teece,1980; Teece,1982) and market power (Scott,1982; Tirole 5illalon 2000).

Theoretical litera e on ersification discount argues that firms diversify in order to reduce risk. Mansi and Ree - 2002) arg. their empirical paper that diversification discount arises due to the risk-reducing cende vies of the conglomerates. They further argue that diversification reduces shareholder vatu $n t^{1}$ erone hand but increases the bondholder value due to the reduction in risk. As a result it ma expe ed that more diversification discount exists in firms with debt as compare to 1 equit sins. After using the Berger and Ofek (1995) methodology they find a disco of $4 \%$ in firn $s$ with more than average debt levels whereas no discount is found for all equity $\mathrm{h}$ alt suggests that debt is an important factor in determining firm diversification. They also w that using book values of debt instead of market values of debt for calculating excess value ndervalues diversified firms. Finally they try to examine the joint impact of diversification on debt and equity holders. Their results show that diversification reduces shareholder value, increases bondholder value but has no impact on total firm value.

Tobin's q became the most common measure of firm performance after Lang and Stulz (1994). They use three different measures of diversification to compare the q ratio of single segment firms with multi-segment firms for various levels of diversification. The first two measures are Herfindahl indices constructed from sales and assets. The third measure is the number of segments in the firm since more diversified firms have more segments. Lang and Stulz (1994) use crosssectional regressions for each year from 1978 to 1990. They use a dummy variable to estimate the statistical contribution to $q$ of diversification. However, they argue that since this method does not take into account the industry effects, a firm belonging to an industry with low q will automatically 
have lower q irrespective of diversification. This short coming is corrected for by using industryadjusted measures of discount.

Berger and Ofek (1995) use asset and sales multiplier14 instead of Tobin's q in order to measure the value effect of diversification. In order to show the possible association between value loss and diversification they estimate pooled regressions using multi-segment dummy and control for firm size, profitability and growth opportunity of the firm. Khanna and Palepu (2000) use Tobin's q and rate of return on assets (ROA) as a measure of firm performance. Four different diversification measures are used in their analysis: (a) INDCNT: a count of industries represented in a group, (b) ENTROPY: sum of entropy index of related diversification and an entropy index of unrelated diversification, (c) CONCENTRIC: a weighted average of each firm's share of group sales and (d) HERFINAHL: sum of squares of each industry's sales as a proportion of tatol group sales. Both Univariate comparisons and Multivariate regression analysis are prorme sing Tobin's q and ROA.

Schoar (2002) adopts a different methodology to address the issue of whethe versific cion destroys value or not. He uses micro level data for manufacturing firm from the gir dinal Research Database from the U.S. Bureau of the Census. Instead of using arket yation Measures such as excess value of the firm he uses productivity measures of firp per ance lil total factor productivity (TFP). TFP measures of firm performance are obtaine at the pl leve by estimating a log-linear Cobb-Douglas production function for each industry at ear. Num of segments and Herfindahl index are used as measures of diversification. He con for firm size and segment size in his regressions. Schoar (2002) tests several differem hypothe $\mathrm{c}$ his paper and uses different dummies to do so.

Anderson et al.(2011) reviewed that whether co brate divers fication decreases or increases the risk of the diversifying firm is an important empiric uestion. They investigate this issue using a sample of diversifying acquisitions and various roures. They find that corporate diversification tends to decrease the risk of son but increase the risk of many others, and on average corporate diversification does not low fi 1 . These findings call into question the notion that corporate diversification strintly reduc firm nsk.

Raei et al(2015) examined th re on betu en diversification, performance and risk. They used ROE as a proxy of perforp. an Herfind a a proxy of diversification. They found any relation between diversificand th thentromance and risk.

\section{THE PROPOS DS TY}

Based on the awelopmen of the literature, several hypotheses are developed. The first hypothesis is stat d:

$\mathbf{H}_{1}$ : There is a fice it rela onship between diversification strategy and firm performance.

The second hypoth is as flows:

$\mathbf{H}_{2}$ : The Is $_{\text {ignifio }}$ lationship between diversification strategy and risk.

In th vape we use Aerfindahl index for measure of diversification. The HERFINDAHL coefficio year $t$ is calculated as follows:

$\mathrm{HERF}_{\mathrm{i}, \mathrm{t}}=\Delta$ SALE/SALE $)^{2}$

Where:

HERF $_{\mathrm{i}, \mathrm{t}}$ : sales revenue according to HERFINDAHL indicator for firm $\mathrm{i}$ in year $\mathrm{t}$.

SSale: seles a certain portion of the company

Sale: The total sales (i.e., the total sales of parts)

HERF variable for one part companies equal to 1 . For companies that are more than one part is less than 1 . So, the smaller coefficient indicates a greater extent of corporate diversification.

Also Tobins'q and ROA as measures of firm performance are as follows:

Tobins'q = Total market value of firm/ Total asset value

ROA $=$ Net profit/Total assets

The risk (STD): The total risk of the firm is estimated from the market data. It is appreciated by the standard deviation of stock returns. 
In this paper three variables are control variables:

The size of firm (SIZE): It is essential to control the size of the firm sample that is supposed to act on the performance. We kept as variable of control the size of every firm measured by the logarithm of the total asset of the group.

The growth of the firm (GROWTH): The growth of the company is one of the explanatory factors the most important of the performance of firms. This variable is measured by the average variation of the turnover on the reporting period. That is:

$$
\text { GROWTH }=\frac{\text { Sales }_{\mathrm{n}}-\text { Sales }_{\mathrm{n}-1}}{\text { Sales }_{\mathrm{n}-1}}
$$

The debt (DEBT): The variable of the debt is measured as the ratio of the total debts and the shareholders equity.

We choose 63 firms from companies listed in Tehran Stock Exchange. The data use in th ting model is extracted from TSE that provide from 2008 to 2012. The panel model is $\mathrm{d}$ in this $\mathrm{P}$ er. The results

As it is mentioned, the sample is composed of 63 companies listed in Tehr a Stock E ang The methodology for analyzing data is based on panel modeling. In the fir the t finda mdex is based on distribution of the sales by activity which allows the de fil 1 the $d$ ersification strategy level for each firm. The data being in both time series ar a cross so nal. Ne have thus made regression using a panel data.

Table 1, hereafter resumes the descriptive statistics of the iable the whole period (20082012): mean, median, maximum, minimum and standard cersion. The variable is measured by Herfindahl index (HERF). The perform ice is evaluated oy the ROE. The risk is measured by standard deviation of the return equity ( $S$ D). The log f total asset measures the size of the firm (SIZE). The (DEBT) variable correspondin total deb/total equity, presents the debt of the firm. The growth (GROWTH) is measured by the The number of observation is 315 .

Table 1. Desci tive Sratistics

\begin{tabular}{|c|c|c|c|c|c|c|}
\hline Variables & N/valid & Mera & Median & Std. Deviation & Maximum & Minimum \\
\hline Tobin's q & 315 & & 1.05 & 0.22 & 2.50 & 0.25 \\
\hline Ln(Tobin's q) & 315 & & & 0.25 & $1 / 01$ & -0.40 \\
\hline ROA & 315 & & 7.02 & 10.3 & 30.2 & -5.2 \\
\hline STD & & & 9.82 & 6.91 & 44.08 & 0.00 \\
\hline $\operatorname{Ln}(\mathrm{STD})$ & & & 2.38 & 0.61 & 3.81 & 0.00 \\
\hline HERF & & 0. & 0.64 & 0.24 & 1.00 & 0.08 \\
\hline SIZE & & 5.88 & 5.77 & 0.62 & 7.70 & 4.29 \\
\hline DEBT & & 2.36 & 1.87 & 2.18 & 13.19 & -3.68 \\
\hline GROY' & & 0.21 & 0.15 & 0.35 & 1.60 & -0.80 \\
\hline
\end{tabular}

- $\mathrm{N}^{\mathrm{T}}$ mal $\mathrm{d}$ tribution of the dependent variables

Norman sion model remaining is one of the regression assumptions that illustrate the validity or regression tests. Then using Kolmogorov- Smironov test normality of dependent variables dis sution is investigated. Because the normality of dependent variables leads to normality of remains of model (Difference between the estimated values of the real data) So, it is necessary control the dependent variable controlled before the estimate parameters and if this condition was not available take good solution for making them normal (conversion). The null hypothesis and hypothesis 1 in this test is written as follow:

$\left\{\begin{array}{l}H_{0} \text {. Data for the dependent variable follows a normal distribution. } \\ H_{1} \text {. Data for the dependent variable not follows a normal distribution. }\end{array}\right.$

Meaningful value for return standard deviation and tobin's q variables during studied years are less than 0.05. so, null hypothesis is rejected for these variables. Normal distribution of variables in 
different years is not normal but the values of these variables logarithm in these years are more than 0/05. So their distribution has been normal and Meaningful value for ROA variable during studied years is more than 0.05 .

Table 2. Test Kolmogorov - Smironov

\begin{tabular}{|c|c|c|c|c|c|c|c|c|}
\hline \multirow[b]{2}{*}{ Variable } & \multirow[b]{2}{*}{ Number } & \multicolumn{2}{|c|}{ Normal parameters } & \multicolumn{3}{|c|}{ Most Extreme Differences } & \multirow[b]{2}{*}{$\begin{array}{l}\text { Kolmogorov- } \\
\text { Smironov Z }\end{array}$} & \multirow{2}{*}{$\begin{array}{l}\text { Asymp. } \\
\text { Sig. } \\
\text { (2-taile) }\end{array}$} \\
\hline & & Mean & $\begin{array}{c}\text { Std. } \\
\text { deviation }\end{array}$ & Absolute & Positive & Negative & & \\
\hline Tobin's q & 315 & 1.2 & 0.22 & 0.2 & 0.2 & -0.12 & 1.32 & 0.01 \\
\hline Ln(Tobin's q) & 315 & 0.18 & 0.25 & 0.15 & 0.1 & -0.15 & 1.15 & 0.08 \\
\hline ROA & 315 & 9.2 & 10.3 & 0.11 & 0.11 & -0.09 & 1.01 & 0.15 \\
\hline STD & 315 & 10.95 & 6.91 & 0.11 & 0.11 & -0.07 & 1.87 & 0.002 \\
\hline $\mathrm{Ln}(\mathrm{STD})$ & 315 & 2.32 & 0.61 & 0.07 & 0.05 & -0.07 & & 989 \\
\hline
\end{tabular}

In this study we have two hypotheses. For each hypothesis, we analyze data.

- Panel Analysis $\mathrm{H}_{1}$

For data analysis of the panel analysis (Panel) without fixed effects, wit/ fixed effo an with random effects is used. To determine the effectiveness of model with fix or rar $\mathrm{m}$ eff $\mathrm{s}$ Limer (Chav) test and Houseman test is used. As the table 3 shows, the re Tts nav tes is indicated that the model with fixed effects is better than pooled model. The results of the first model for the first hypothesis test

Table 3. Redundant Fixed Effects T oots of Hypoth

\begin{tabular}{|c|r|r|r|}
\hline Effects Test & Statist & d.f. & Prob. \\
\hline Cross- section F & 6.10 \\
\hline Cross- section Chi- square & 300.1 & $(62,53$ & 0.000 \\
\hline
\end{tabular}

After that we used Hausman test for determin that the fixed effects is appropriate or model with random effects. As the results of $t$ mows, the results of Hausman test indicates that the model with fixed effects is appropriate. $\mathrm{Th}$ siy Acance level for the test of Hausman is 0.012 that indicates the model with dom ef cts is appropriate. The below table shows the results:

Table 4. Correlze and $m$-Fffect $s$ - Hausman Test of Hypothesis 1

\begin{tabular}{|c|c|c|c|}
\hline Test Summar & ChI-Sq.Statistic & Chi-Sq. d.f. & Prob. \\
\hline Cross- section & & 3 & 0.012 \\
\hline
\end{tabular}

The supposed model 1 o tes hypotheses is as follow:

$$
\operatorname{Ln}\left(Q t>\mathrm{O}_{i t}=\alpha_{0}+\mathrm{DIVER}_{i t}+\alpha_{2} \mathrm{SIZE}_{i t}+\alpha_{3} D E B T_{i t}+\alpha_{4} G R O W T H_{i t}+\varepsilon_{i t}\right.
$$

The results of fiy d effe show the probability of significant of $F$ is equal 0.000 . This result means that there is a sic fic nt mo lo The coefficient of determination is equal to 0.07 . The t-statistics for HERF ic-equal $\quad 56$ (m aningless), for SIZE is equal to 0.6(meaningless), for DEBT is equal to -4.37 mea gful a gative), for GROWTH is equal to -0.78 (meaningless)). The below table show res its:

Table 5. Cross- section random effects of model 1 for Hypothesis 1

\begin{tabular}{|c|c|c|}
\hline Variables & Coefficient & t-Statistics \\
\hline C & 1.4 & 3.154 \\
\hline HERF & 0.057 & 0.732 \\
\hline SIZE & -0.201 & -2.690 \\
\hline DEBT & -0.004 & -1.427 \\
\hline GROWTH & 0.012 & 1.20 \\
\hline \multicolumn{2}{|c|}{ Weighted Statistics } \\
\hline \multicolumn{2}{|c|}{0.701} \\
\hline R-Squared & 0.000 \\
\hline Prob (F- statistics) & 1.806 \\
\hline
\end{tabular}


The results of model 1 indicate that there is no significant relationship between Tobin's $\mathrm{q}$ and Herfindahl.

The supposed model 1 to test the hypotheses is as follow:

$$
R O A_{i t}=\alpha_{0}+\alpha_{1} D_{I V E R_{i t}}+\alpha_{2} S I Z E_{i t}+\alpha_{3} D E B T_{i t}+\alpha_{4} G R O W T H_{i t}+\varepsilon_{i t}
$$

The results of fixed effect show that probability of significant of $F$ is equal 0.000 . This result means that there is a significant model. The coefficient of determination is equal to 0.695 . The t-statistics for HERF is equal to 1.676(meaningless), for SIZE is equal to -1.3(meaningless), for DEBT is equal to -0.19 (meaningless), for GROWTH is equal to -0.60 (meaningless)). The table 6 shows the results:

Table 6. Cross- section random effects of model 2 for Hypothesis 1

\begin{tabular}{|c|c|c|}
\hline Variables & Coefficient & t-Statistics \\
\hline C & 30.07 & 1.15 \\
\hline HERF & 3.68 & 1.676 \\
\hline SIZE & -3.26 & -1.3 \\
\hline DEBT & -0.017 & -0.19 \\
\hline GROWTH & 0.2 & -0.6 \\
\hline \multicolumn{2}{|c|}{ Weighted Statistics } \\
\hline \multicolumn{2}{|c|}{0.695} \\
\hline R-Squared & 0 \\
\hline Prob (F- statistics) & \multicolumn{2}{|c|}{} \\
\hline
\end{tabular}

The results of model 2 indicate that there is no signi nt relat onship between Tobin's q and Herfindahl.

So, the results of hypothesis 1 indicate th no significant relationship between diversification strategy and firm performance.

- Panel Analysis $\mathrm{H}_{2}$

For data analysis of the panel an ysis anel) w Cut fixed effects, with fixed effects and with random effects is used. To dete mu he of model with fixed or random effects Limer (Chav) test and Houseman te st 1s use s the table 7 shows, the results of chav test is indicate that the model with effects is 10 than poo rodel.

The results of the secor hypo sis test

T: ble 7. Red ndant Fixed Effects Tests of Hypothesis 2

\begin{tabular}{|l|c|c|c|}
\hline & Statistic & d.f. & Prob. \\
\hline & 2.194 & $(62,15)$ & 0.000 \\
\hline ross- st secton F & 260 & 62 & 0.000 \\
\hline
\end{tabular}

After tha ausman test for determined that the model with fixed effects is appropriate or model with dom effects. As the results of table 8 shows, the results of Hausman test indicates that the mode, with random effects is appropriate. The significance level for the test of Hausman is 0.90 that indicates the model with random effects is appropriate. The below table shows the results:

Table 8. Correlated Random Effects- Hausman Test of Hypothesis 2

\begin{tabular}{|c|c|c|c|}
\hline Test Summary & Chi-Sq. Statistic & Chi-Sq. d.f & Prob. \\
\hline Cross- section random & 0.430 & 3 & 0.901 \\
\hline
\end{tabular}


The supposed model to test the hypotheses is as follow:

$$
R_{I S K_{i t}}=\alpha_{0}+\alpha_{1} D I V E R_{i t}+\alpha_{2} S I Z E_{i t}+\alpha_{3} D E B T_{i t t}+\varepsilon_{i t}
$$

The results of random effect show that probability of significant of $F$ is equal 0.901 . This result means that there is no a significant model. The coefficient of determination is equal to 0.003 . The $\mathrm{t}-$ statistics for HERF is equal to -0.51(meaningless), for SIZE is equal to 0.7(meaningless) and for DEBT is equal to 0.45 (meaningless). The below table shows the results:

Table 8. Cross- section random effects of Hypothesis 2

\begin{tabular}{|c|c|c|}
\hline Variables & Coefficient & t-Statistics \\
\hline C & 7.87 & 2.108 \\
\hline HERF & 0.129 & 0.225 \\
\hline SIZE & 0.002 & 0.008 \\
\hline DEBT & -0.032 & -0.479 \\
\hline \multicolumn{2}{|c|}{ Weighted Statistics } \\
\hline \multicolumn{2}{|c|}{ R-Squared } & 0.000 \\
\hline \multicolumn{2}{|c|}{ Prob(F- statistics) } & 0.9 \\
\hline \multicolumn{2}{|c|}{ Durbin- Watson stat } \\
\hline
\end{tabular}

The results of hypothesis 2 indicate that there is no sign icant relationsh between diversification strategy and risk.

\section{CONCLUSION}

This paper has examined the relationship etw ersification strategy, firm performance and risk. For examined the firm performance, we sed Trbin's q and ROA. The results shown that there is no significant relationship b cwo diversi cation strategy, firm performance and risk.

\section{References}

[1] Amihud, Y., \& L Lè 981).Ris Reduction as a Managerial Motive for Conglomerate Mergers. The Journal Economics, 12(2), 605-617.

[2] Anderson Randy John D.Stowe., \& Xuejing Xing.(2011).Does corporate diversification reduce firn $\mathrm{k} /$ Evide ce from diversifying Acquisitions. Review of Pacific Basin Financial Markats and ies, 1, 3),485-504.

[3] P rger, G., \& Ofek .(1995). Diversification's effect on firm value. Journal of Financial B or

[4] Chen, iung-Jung., \& Chow-Ming Joseph Yu .(2012). Managerial ownership, Diversil ation, and Firm performance: Evidence from an Emerging Market, International Business Review,21(3),518-534.

[5] Choe, C., \& X. Yin .(2009). Diversification discount, information rents, and internal capital markets. The Quarterly Review of Economics and Finance, 49(2),178-196.

[6] Fluck, Z., \& A. W. Lynch.(1999).Why Do Firms Merge and Then Divest? A Theory of Financial Synergy, The Journal of Business, 72(3), 319-346.

[7] Gomes, J., \& D. Livdan .(2004). Optimal Diversification: Reconciling Theory and Evidence. The Journal of Finance, 59(2), 507-535. 
[8] Jensen, M.C.(1986).Agency Costs of Free Cash Flow, Corporate Finance, and Takeovers. The American Economic Review, 76(2), 323-329.

[9] Jensen, M. C., \& K. J. Murphy (1990). Performance Pay and Top-Management Incentives. The Journal of Political Economy, 98(2), 225-264.

[10] Kahloul, Ines., \& Slaheddine Hallara .(2010).The impact of diversification on firm performance and risk: An empirical evidence. International research journal of finance and economics,35,150-162.

[11] Khanna, T., \& K. Palepu .(2000). Is Group Affiliation Profitable in Emerging Markets? An Analysis of Diversified Indian Business Groups. The Journal of Finance, 55(2), 867-891.

[12] Lang, L. H. P., \& R. M. Stulz .(1994). Tobin's q, Corporate Diversificat onl, an Firm Performance, The Journal of Political Economy, 102(6), 1248-1280.

[13] Mansi, S. A., \& D. M. Reeb .(2002).Corporate Diversification: What $G$ ts D unted? The Journal of Finance, 57(5), 2167-2183.

[14] Martin, J. D., \& A. Sayrak .(2003).Corporate diversification and s hoder vô ue. a survey of recent literature. Journal of Corporate Finance, 9(1), 37-57

[15] Maksimovic, V., \& G. Phillips .(2007). Conglomerate Fi M d Interna apital Markets.in B.E. Eckbo, ed., Handbook of Corporate Finance, 1, El we ier B.

[16] Matsusaka, J. G .(2001).Corporate Diversification Value Maximiz con, and Organizational Capabilities ,The Journal of Business, 74(3), 409- 31.

[17] Palich L. E., Cardinal L. B., \& Miller C. C . 90).Cury inearity in the diversification performance linkage: an examination of over uecades of research. Strategic Management Journal ,21(2), 155-174.

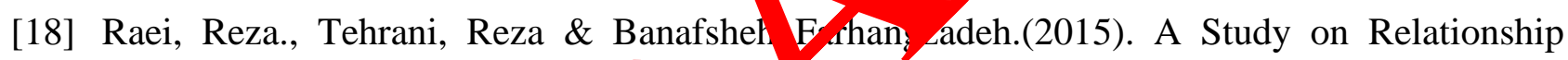
between Diversification Strateo rm Per rmance and Risk: Evidence from Tehran Stock Exchange. International jour al of siness a social science.6(1),112-118.

[19] Rajan, R., H. Servaes., \& The cost of diversity: the diversification discount and inefficient investr ent. Journ. finance, 55(1), 35-80.

[20] Shleifer, A., \& R V. W Y.(1989).Management Entrenchment: the case of manager specific investment. Jo a of Fin ial Economics, 25(1), 123-139.

[21] Shleifer, \& W. Vișny.(1992).Liquidation Values and Debt Capacity: A Market Equilibrius vr oach. The Journal of Finance, 47(4), 1343-1366.

[22] Scb in, D. 99\%.The dark side of internal capital markets II: Evidence from diversified nglon rates. N $\subset \mathrm{R}$ Working Paper Series, 6352.

[23] Sc. S., \& J. C. Stein .(2000). The dark side of internal capital markets: divisional Rent ling and inefficient investment. Journal of Finance 55(6), 2537-2564.

[24] Schoar, A.(2002).Effects of Corporate Diversification on Productivity. The Journal of Finance, 57(6), 2379-2403.

[25] Scott, J.T.(1982).Multimarket Contact and Economic Performance. The Review of Economics and Statistics, 64(3), 368-375.

[26] Stein, J.C.(1997).Internal capital markets and the competition for corporate resources. Journal of Finance, 52(1),111-133.

[27] Stein, J. C .(2003). Agency, Information and Corporate Investment.in G. M. Constantinides, M. Harris and R. Stulz, ed., Handbook of the Economics of Finance, Elsevier Science B.V. 
[28] Teece, D. J .(1980). Economies of scope and the scope of the Enterprise. Journal of Economic Behavior \& Organization, 1(3), 223-247.

[29] Teece, D. J .(1982). Towards an economic theory of the multiproduct firm. Journal of Economic Behavior \& Organization, 3(1), 39-63.

[30] Tirole, J. (1995). The Theory of Industrial Organization. Cambridge, MA: MIT Press.

[31] Villalonga,B.(2000).An Empirical Analysis of Diversification Motives. Unpublished Manuscript, Los Angeles, Anderson Graduate School of Management, University of California.

[32] Villalonga, B .(2004). Diversification Discount or Premium? New Evidence from the Business Information Tracking Series. The Journal of Finance, 59(2), 479-506

[33] Wernerfelt, B., \& Montgomery, C. A.(1988).Tobin's q and the importan focus in irm performance. American Economic Review, 78(1), 246-250.

[34] Williamson ,O.E.(1970).Corporate Control and Business Behay or: An Inquil ito the Effects of Organizational Form on Enterprise Behavior. Englewgoa iff. AN.J, $\mathbf{f}$ encice Hall.

[35] Williamson, O. E.(1975). Markets and Hierarchies: Anal sis and itrus Implications. Collier Macmillan Publishers, Inc., NY.

[36] Zuckerman, E.W.(1999).The Categorical Imperative: Curities ysts and the Illegitimacy Discount. American Journal of Sociology, 104(5), 398-1397.

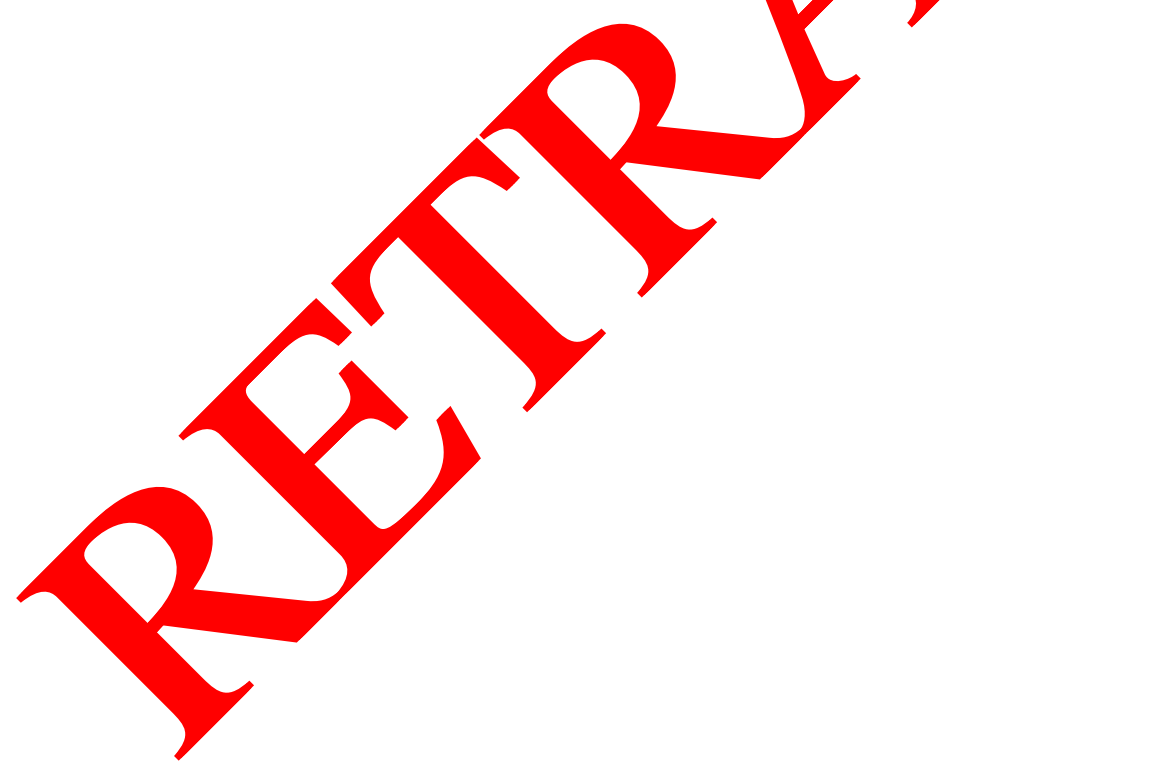

